As a collector in the field Granger had very few equals. By long experience he seemed to have acquired an extra sense which led him to the places where the best things were to be found and, when discovered, his superb skill in their excavation and preservation, the result of his acquired knowledge and great pationce, came into play, as many a specimen in the galleries of the American Museum bears permanent witness.

$\mathrm{H}_{\Theta}$ was, however, far from being only a skilled collector. His scientific work, chiefly on the mammals of the Eocene Period, if not as great in quantity as that of some of his colleagues, was in no way behind in quality. His papers are models of clarity and conciseness which students would do well to study.

Granger was a most lovable character, entirely loyal to his friends and colleagues and to the American Museum. He was almost unduly modest about his own attainments, but he never withheld sound and generous advice whenever his help was asked. His quiet sense of fun and his good humour and unperturbability over the various worries incident to expeditions will be well known to those that have had the opportunity of being with him in the field.

Born in Vermont, he left for New York at an age too early for a university training, but towards the ond of his career Middlebury University of his native State honoured him and itself with a doctorate honoris causa.

Granger was one of a band of vertebrate palæontologists who gathered around the late Prof. Henry Fairfield Osborn, and in his career of just over fifty years in the American Museum he performed a life work which is a monument to his memory.

C. Forster-Cooper.

\section{Prof. W. H. Heaton}

THE death on October 20 of Prof. W. H. Heaton at the age of eighty-five brought to an end a personal association with University College, Nottingham, almost from its beginning.

William Haslam Heaton, born at Bolton in 1856, attended Manchester Grammar School, where he won an open scholarship at Brasenose College, Oxford. He had a distinguished university career and gained the highest distinctions in both mathematics and physics. He was appointed lecturer and senior demonstrator in the Clarendon Laboratory of Physics at Oxford, and was repeatedly appointed examiner to the Universities of Oxford, Durham and Sheffield.

In 1884 he became professor of mathematics and physics at University College, Nottingham, which had been opened only three years before. There were flourishing evening classes, but scarcely any day students. Prof. Heaton's popular evening lectures on scientific subjects were very successful, but a more difficult task was to build up the full-time day work. One step forward was when an Education Department was opened in 1890. In this he played a leading part, as also in setting up a Department of Engineering, which was later followed by a Department of Mining.
Prof. Heaton became vice-principal in 1896, and in 1906 his teaching responsibilities were lightened by the establishment of a separate chair of physics ; this gave him more time for consideration of general College policy. In spite of his own tastes lying in the direction of science, he clearly perceived that the development of the College had been one-sided, with the Faculty of Arts lagging far behind. In 1911 he became principal, and at once instituted new professorships of English and mining, to be followed later by several other chairs. Many developments in general policy were made at the same time, and the status of the College soon began to rise. This progress was checked by the outbreak of war in 1914, but a new period of rapid development began in 1919 . New laboratories were opened and emergency accommodation of every possible kind was added, but the College grew too large for its existing site. Then came the splendid benefactions of Lord Trent and the opening of new College buildings at University Park in 1928.

Prof. Heaton retired in 1929, but still retained an active interest in College affairs and was repeatedly consulted by his successors in the principalship. His death represents a very great loss to the College he served so well.

H. T. H. Piaggio.

\section{Prof. S. Kopeć}

NEws has been received that Prof. Stefan Kopec, professor of biology in the University of Warsaw, and his son were among those executed near Warsaw as a reprisal for the killing of a Polish 'quisling'. In his early days Kopeć worked on the metabolism of insects with Prof. Garbowski at Cracow. After work on growth in rabbits at the Polish National Institute for Rural Economy at Pulawy he went with a Rockefeller fellowship to the Department of Animal Genetics at the University of Edinburgh. On his return he published a very extensive series of papers on growth and the body proportions of mice. In 1932 he was appointed professor in charge of the Biological Laboratory of the University of Warsaw where he continued his studies on growth. Lately he had been engaged in experimental studies on density of population problems as affecting fertility and growth. His death is a great loss to biological science.

WE regret to announce the following deaths :

Dr. E. S. Beaven, the well-known agricultural botanist and plant breeder, on November 12, aged eighty-four.

Dr. J. A. Hood, founder of the Hood chair of mining in the University of Edinburgh, on November 19, aged eighty-two.

Prof. Wal her Nernst, For. Mem.R.S., professor of physical chemistry in the University of Berlin, aged seventy-seven.

Mr. J. F. F. Rowland, formerly public analyst for St. Marylebone, an authority on analytical and bacteriological examination of foodstuffs and water, on November 2, aged seventy. 